Public Choice

DOI 10.1007/s11127-010-9721-7

\title{
Appropriation, violent enforcement, and transaction costs: a critical survey
}

\author{
Mehrdad VAHABI (University of Paris 8)
}

\begin{abstract}
This paper focuses on the extension of transaction costs to appropriative activity and coercive power in the property rights approach. It has been argued that including the costs of appropriation and violent enforcement in transaction costs is based on the assumption that Coaseian bargaining can be extended to any institutional scenario, i.e., voluntary as well as coercive exchange. However, voluntary transactions cannot capture the logic of coercive power. This means that the assumption of an efficient political market is not valid, and that the "Political Coase Theorem" lacks the logical consistency to provide a cornerstone for political theory.
\end{abstract}

Keywords: Appropriation, Hobbesian state, Political Coase Theorem, Property rights approach, transaction costs, violent enforcement.

JEL Classifications: D74; H11; H41; N40 


\title{
Appropriation, violent enforcement, and transaction costs: a critical survey
}

\author{
Mehrdad VAHABI (University of Paris 8)
}

\section{Introduction}

Economists have identified two different methods of resource allocation, which are aptly described by Pareto (1927/1971: 341) as follows: "The efforts of men are utilized in two different ways: they are directed to the production or transformation of economic goods, or else to the appropriation of goods produced by others." "Trade" and "raid" are two different activities based on protection of rights and aggression through coercive means, and violent enforcement is the external enforcement of contracts through coercive means. Within this framework, the state may be characterized as a third-party violence-using enforcer that is assumed to protect legal agreements or contracts. The idea of protection is ambivalent, however, since it includes both itself and its antithesis: aggression. In this sense, protection and aggression costs (Tilly 1985) involve not only the costs of state warfare and related military technology, but also costs related to other violence-using agencies (such as Mafialike organizations, ${ }^{1}$ private security, and military corporations), civil military mobilizations, and socio-political conflicts. The costs of weapons for self protection, locks, and security cameras and other surveillance devices, should also be added to this long list.

Recent economic literature on conflict theory usually treats "protection and aggression costs" as part of transaction costs (Anderson and Marcouiller 2002, 2005; Skaperdas and Syropoulos 2002), or as costs incurred by any other non-violent appropriative activity, such as money laundering and lobbying (Long and Sorger 2004). Garfinkel and Skaperdas (2007: 690) conducted a comprehensive survey of economic modeling of conflictual relationships and noted, "Another way to think of the conflict costs (...) in relation to trade and exchange is as a large component of the often-discussed, yet rarely modeled or operationalized concept of 'transaction costs."”

However, not all economists support this line of reasoning. For example, in their analysis of guard labor (e.g., human resources devoted to the exercise of power), Jayadev and Bowles (2006) examined the nature of this particular type of monitoring and protection activity and questioned whether its costs could be classified as transaction costs. In the standard labor model, monitors are classified as guard labor, and the cost of employing them is classified as

\footnotetext{
${ }^{1}$ Barzel (2002: 263) noted, "Another substitute for the state's third-party enforcement is organized crime."

2 Many modellers do not even discuss the economic nature of protection costs (see, for example, Stefanadis 2007) or simply exclude any type of appropriative costs (Tornell and Velasco 1992; Tornell and Lane 1999). For a detailed critical survey of conflict theory, see Vahabi (2004, 2009b, 2010a).
} 
a transaction cost. But what about wages that are paid in excess of the workers' next best alternatives to elicit higher levels of labor effort? Is this excess also part of transaction costs? This question is important when we consider that one in four individuals in the United States is currently engaged in guard labor, providing security for people and imposing work discipline (Bowles and Jayadev 2007). Jayadeve and Bowles (2006: 335) wrote, "Guard labor bears no obvious relationship to transaction costs (...) And while prison guards or military personnel represent guard labor, it is unclear which transactions their costs underwrite". Olson (2000: 63) took a more theoretical approach and also denied that transaction costs applied to violent enforcement: "A theory of Coasian bargains and the transactions costs that limit them does not explain the outside power that enforces contracts. It could easily be extended to explain why those who want to engage in transactions that require third-party enforcement want such enforcement, and why they would often be willing to pay something for it. But it cannot explain why coercive power is sometimes used to make markets work better by enforcing contracts and to take the goods that are traded in markets."

So, what are transaction costs and what can be included in them? A narrow definition of transaction costs restricts them simply to costs of trading (Demsetz 1964). Demsetz (1988: 64) noted, "Transaction cost may be defined as the cost of exchanging ownership titles." This narrow definition of transaction costs can be termed "neoclassical," although Demsetz is classified as one of the "property rights economists" who remains "a staunch, though perhaps lonely, proponent of this view" (Allen 2000: 903). It is worth noting that Coase's 1937 definition of transaction costs as the "costs of using price mechanisms" contributed to the neoclassical approach to transaction costs, which excludes raiding costs from transaction costs.

According to Allen (2000: 905), the "property rights approach" provides a broad definition of transaction costs, including both trading and raiding costs: "The importance of the Coase theorem then is that it points to transaction costs as the necessary factor in any explanation of the distribution of property rights. The definition of transaction costs, therefore, must be those costs that cause the Coase theorem to not apply" (emphasis added). Therefore, the inclusion of raiding, aggression, and protection activities into transaction costs appears to be derived from the extension of the Coase theorem (Coase 1960). Interestingly, this broad definition is justified in reference to the theorem but not to economic reality.

Like all stories, Allen's "tale of two histories" (neoclassical and property rights approaches to transaction costs) is not entirely true. The "property rights" approach includes two distinct traditions: one emphasizes the measurement and enforcement of property rights; the other emphasizes the quality or performance of contractual agreements (Alchian and Woodward 1988; North 1990a). The former could be termed the "University of Washington" branch of the property rights approach (Barzel 1977, 1982, 1997; Cheung 1969, 1970, 1974; North 1981, 1990a, b), and the latter is known as the "asset-specificity" branch (Williamson 1975, 1979, 1985, 1996). The University of Washington branch maintains a broad definition of transaction costs, and the asset-specificity branch advocates an intermediary definition of transaction costs that excludes raiding and violent enforcement but embraces all forms of 
"governance structures" (markets, firms, and hybrid forms of contractual relationships). By modifying Allen's terminology, we can distinguish three different definitions of transaction costs (see Table 1): (1) neoclassical; (2) asset-specificity intermediary; and (3) University of Washington broad definitions.

Table 1. Three definitions of transaction costs and the Coase theorem.

\begin{tabular}{|c|c|c|c|}
\hline Type of approach & $\begin{array}{c}\text { Definition of } \\
\text { transaction costs }\end{array}$ & $\begin{array}{c}\text { Limits of the Coase } \\
\text { theorem }\end{array}$ & Authors \\
\hline Neo-classical & $\begin{array}{c}\text { Narrow: } \\
\text { Market exchange (trade) }\end{array}$ & $\begin{array}{l}\text { Voluntary inter-firm } \\
\text { transactions and } \\
\text { bargaining }\end{array}$ & $\begin{array}{l}\text { Hicks (1935), } \\
\text { Coase (1937) }\end{array}$ \\
\hline $\begin{array}{l}\text { Property rights (asset- } \\
\text { specificity branch) }\end{array}$ & $\begin{array}{c}\text { Intermediary: } \\
\text { Governance structures } \\
\text { (market, firm or } \\
\text { hierarchy, hybrid forms) }\end{array}$ & $\begin{array}{l}\text { Voluntary inter-firm } \\
\text { and intra-firm } \\
\text { transactions (internal } \\
\text { organization) }\end{array}$ & $\begin{array}{c}\text { Coase (1937), } \\
\text { Cheung (1969), } \\
\text { Williamson (1975, } \\
1985,1996)\end{array}$ \\
\hline $\begin{array}{c}\text { Property rights } \\
\text { (University of } \\
\text { Washington branch) }\end{array}$ & $\begin{array}{c}\text { Broad: } \\
\text { Trade and raid } \\
\text { (governance structures } \\
\text { and state) }\end{array}$ & $\begin{array}{c}\text { Voluntary } \\
\text { transactions and } \\
\text { coercive power } \\
\text { (Political Coase } \\
\text { Theorem) }\end{array}$ & $\begin{array}{l}\text { Cheung (1970) } \\
\text { Coase (1960, } \\
\text { 1988b,c), North } \\
(1989,1990 \mathrm{~b})\end{array}$ \\
\hline
\end{tabular}

Differences in how transaction costs are defined can have considerable effects, from quantitative or theoretical perspectives. With regard to the quantitative aspect, if transaction costs are defined broadly, what costs will make the Coase theorem inapplicable?

Wallis and North (1986) addressed this question by measuring the level of transaction costs over 100 years (1870-1970). They assessed what was meant by the "transaction sector" (Wallis and North 1986: 100-103) and whether this should be subtracted from the gross national product (GNP): "We measured the transaction sector by taking all the resources used in the 'transaction industries' (wholesale and retail trade; and finance, insurance and real estate, FIRE) and adding wages paid employees in transaction-related occupations in all other industries, the 'non transaction' industries. These occupations encompass managers, supervisors, clerical workers, and employees in purchasing and marketing departments (...) indeed, they account for almost half of GNP in 1970" (Wallis and North 1988: 651, 653). However, their calculations neglected the costs incurred in organizing tribunals, police, guards, army, security agencies, private mercenary corporations, surveillance systems, and so on.

Should other costs be included as "transaction costs"? North (1992: 8) claimed that "ideological attitudes and perceptions" should be considered independent variables when determining transaction costs. If so, transaction costs should include the operating costs of anything that is used to shape or influence public opinion: churches, political parties, religious sects, intellectual circles, and education systems. The definition becomes so broad that it covers "all costs incurred in operating an economic system" (North 1992: 6). Hence it is not possible to quantify all the costs of rendering the Coase theorem inapplicable, nor is it possible to measure their magnitude. This explains why Wallis and North finally (and 
paradoxically) adopted the narrow or neoclassical definition of transaction costs to measure the level of transaction costs.

Differences between the narrow, intermediary, and broad definitions of transaction costs are more relevant from a theoretical perspective, particularly with regard to the limits of the Coase theorem. Schlag (1989: 1675) pointed out that "an overly expansive view of transaction costs threatens to make the Coase theorem tautological. On the other hand, an overly restrictive view of transaction costs can effectively invalidate the theorem."

The Coase theorem is the cornerstone of two branches of the property rights approach. However, they diverge radically on the scope of applicability of the theorem. While the assetspecificity branch limits the theorem's applicability to voluntary transactions, the University of Washington branch extends it too far and includes appropriative activity, coercive power, and politics. This extension is termed the "Political Coase Theorem (PCT)". The advocates of PCT stretch the definition of transaction costs to include costs associated with aggression and protection.

In the property rights approach, the concept of transaction costs is theoretically related to the Coase theorem. This is not the case for authors who use the concept more loosely. A loose usage of the concept does not entail a "zero transactions costs" qualifier for the allocative efficiency. As Buchanan stresses (1987: 154): "The central argument in Coase's seminal 1960 paper, "The Problem of Social Cost," is that voluntary exchange in well-defined rights provides a sufficient condition for allocative efficiency. Coase amended this central proposition by what has been widely interpreted as a "zero transactions costs" qualifier, which, as I shall demonstrate, weakened the force of his argument." When this qualifier is not regarded as a sufficient condition for allocative efficiency, then transaction costs are irrelevant in determining the institutional arrangements.

For example, Berggren and Karlson (2003) analyze constitutionalism and division of power in terms of "political transaction costs". They maintain that these costs have two components: 1) costs associated with difficulties in reaching an agreement because of differing preferences among political actors; and 2) costs stemming from an imposed difficulty in reaching an agreement "due to the set of political institutions in place, defining the collective decision mechanism" (Berggren and Karlson 2003: 104). Although the authors are inspired by North's definition of transaction costs (North 1990a), they do not follow him in assuming a Political Coase Theorem. Nor do they assume a "zero transaction costs" qualifier in which the set of political arrangement is irrelevant. They prefer the concepts of "low transaction costs" and "high transaction costs."3 The former describes a "strong ability to act" politically, and the latter implies a "weak ability to action."

\footnotetext{
${ }^{3}$ In the property rights approach, the 'high' and 'low' transaction costs have no theoretical meaning without the assumption of a state of zero transaction costs. It is only in such a state that the Coase theorem is valid and not in a state of "low" transaction costs. For a critical appraisal of replacing the concept of "zero" transaction costs with "low" transaction costs, see Medema and Zerbe (2000).
} 
In fact, for Berggren and Karlson, high transaction costs might be a source of public good, if they are associated with division of power. In designing political institutions, it is sometimes desirable not to act. In such cases, high transaction costs enhance public interest. Following Buchanan (1986, 1987), these authors are more interested in the rule governing the transaction than the outcome of the transaction. It is not the amount of transaction costs (low or high) that determines the efficiency, but the rule of transaction (division of power) that decides the value of institutional arrangements.

I do not take issue with a loose utilization of the transaction costs concept even in the realm of politics since my concern is not terminological. Instead, I am more interested in how the concept is used theoretically in the property rights approach with reference to Coase theorem and its efficiency implications.

Within this context, two questions need to be addressed. First, do the two branches of property rights produce the same results with regard to transaction costs of generic and idiosyncratic assets? If their results are contradictory, then a further investigation of the Coase theorem and its extension to involuntary transactions will be necessary to test the internal consistency of the property rights approach. This leads to the second question: Under which assumptions can transaction costs be extended to appropriative activity and violent enforcement, and are such assumptions consistent with the Coase theorem? The answer to the second question must incorporate Coase's personal responsibility for the PCT, as well as his followers' contributions to a more definitive version of the PCT. It is also important to keep in mind that extending Coaseian bargaining to politics will have major practical implications, because the PCT implies efficient political markets and institutions.

I conducted a critical survey of how the property rights approach can be used to extend transaction costs to include appropriative activity and coercive power. In the second section of this paper I describe the basic theoretical framework of the asset-specificity branch, which extends transaction costs to include governance structures but excludes appropriative activity and violent enforcement. Next, I discuss the alternative setup proposed by the University of Washington branch of the property rights approach; this model includes both appropriative activity and violent enforcement in transaction costs. I also explore how these two branches produce contradictory results with regard to the transaction costs of generic and idiosyncratic assets, and investigate to what extent the contradiction is related to how the Coase theorem was formulated initially. In the fourth section of this paper, I examine the Coase theorem in relation to appropriative activity. The fifth section will discuss the logical contradiction that appears when the Coase theorem is extended to include coercive power and politics, and will demonstrate the invalidity of the Political Coase Theorem and the assumption of an efficient political market. The last section concludes.

\section{In the beginning there were markets}

Two seminal papers by Coase $(1937,1960)$ inspired the two branches of the property rights approach. The first paper was almost ignored when it was published in 1937, but it was 
rediscovered after the great popularity of his second paper in 1960. Coase actually wrote the second paper to expose the weaknesses in Pigou's analysis of the divergence between private and social products; Coase was not trying to establish a new "theorem," as was claimed later by Stigler (1966: 113). Coase (1992: 717) wrote, "It was only later and in part as a result of conversation with Steven Cheung in the 1960s that I came to see the general significance for economic theory of what I had written."

Cheung undoubtedly played a major role in generalizing Coase's idea about transaction costs. In his first seminal paper, Coase (1937) used examples relating transaction costs exclusively to market or price mechanisms; Cheung (1969) was the first to claim that the choice of any contractual setup, including internal organization of a firm, depended on transaction costs. $\mathrm{He}$ illustrated his argument through an analysis of share tenancy. In this way, Cheung's work preceded that of Williamson, who proposed the concept of "governance structures" (Williamson 1975, 1979, 1985), which extends transaction costs to markets, firms/hierarchies, and hybrid forms.

Demsetz (2008: 107) remained loyal to Coase's (Coase 1937) initial definition of transaction costs as the "cost of using the price mechanism" and rejected the extension: "I use transaction cost to mean no more and no less than what Coase describes as the cost of using the price system. The stipulation is necessary because later writers broadened the meaning of transaction to include the costs of information and of cooperation between parties whether these costs are incurred in exchange across markets or in any other setting, such as in managing workers within a firm. Coase clearly meant to distinguish costs incurred to manage resources within the firm from costs incurred to interact across markets at market-determined prices, and I wish to preserve this distinction."

In dire contrast with Demsetz, Williamson denied this distinction. In doing so, he was inspired by Cheung's particular reading of Coase's first seminal paper (Coase 1937). Nevertheless, it is important to note that Williamson's understanding of the "firm" was not identical to what Cheung considered Coase's concept of the firm: according to Cheung (1970: 56), "the firm is but a holder of contracts." Interestingly enough, Demsetz (1997: 6) shared the same idea: "The firm is itself a nexus of contracts." To Williamson, however, the firm was not a "nexus of treaties" (Williamson 1989), because it "is its own court of ultimate appeal" (Williamson 1992: 340). Williamson argued that market contracts must be distinguished from intra-firm contracts. This distinction is justified according to the existence or absence of confidence. A firm must establish confidence between its members, because in case of disputes, resorting to a legal authority is costly and inefficient. Some courts even refuse to hear certain intra-firm disputes over technical issues; in these cases, an internal arbitrator is more convenient to resolve disputes. Accordingly, hierarchy is its own court of ultimate appeal, and the court is not just outside the firm. ${ }^{4}$ Williamson described the firm as a "hierarchy" to stress its

\footnotetext{
${ }^{4}$ For a more detailed analysis of how this aspect of the firm relates to contractual incompleteness, see Vahabi (2002).
} 
distinction from the market. Therefore, the major issue is the frontiers of the firm and the comparative advantage of different governance structures within capitalism. Asset-specificity literature revolves around this central problem.

Williamson (1975: 20) addressed this issue by assuming "for expositional convenience, that in the beginning there were markets." This statement has been extensively criticized from epistemological as well as historical perspectives: a vast body of critical literature developed ${ }^{5}$ following the initial challenge by Hodgson (1988: 177-182). Ankarloo and Palermo (2004) published an excellent synthesis of all preceding criticisms of Williamson's notorious assumption. Interestingly, all of this discussion focused on the primacy of the firm (production) over the market; critics never questioned why Williamson did not start with an anarchic or Hobbesian state. By assuming an initial state of markets instead of a Hobbesian state, Williamson narrowed the scope of transaction costs to non-coercive relationships and particularly to modern capitalist economies.

From a historical perspective, capitalist institutions stem from violence and coercion. However, it is not logically necessary that markets be founded through violence. In fact, today's mature market economy and its institutions are not established upon violence. From a theoretical point of view, analyses of capitalism do not require the assumption of a coercive or supra-economic force. Therefore, Williamson's expositional convenience not to start with a Hobbesian state was theoretically coherent and even compatible with a Marxian perspective. ${ }^{6}$

\footnotetext{
${ }^{5}$ See for instance Fourie (1993: 44); Dietrich (1994: p. 17); Ankarloo and Palermo (2004); Milonakis and Fine (2007: 48).

${ }^{6}$ From a Marxian perspective, Palermo (2000: 580) is correct in claiming that "as far as method is concerned, Williamson's historical analysis is peculiar: the statement that capitalist institutions originated without any coercion is not documented historically." The initial phase of capitalist development, the so-called "primitive accumulation of capital" (Smith 1776/1961) was also marked by the direct use of coercive, extra-economic means, such as military conquests, imperialism, plunder, pirating, colonialism, triangular slave trade, and enclosure laws in Great Britain (Marx 1867/1978, vol. 1, ch. 24). The subordination of labor and its total separation from the means of production usually begins with dependent rather than free labor. Large-scale military conquest contributed to dependency and slavery. "Slavery might be extended to members of the same people through debt bondage or through the selling by a chief of his own surplus labor to a more civilized society, but the model for both was conquest slavery" (Mann 1986: 151; emphasis added). Forced labor or largescale military-style organization of labor should not be confused with slavery: "As compulsion became institutionalized, it needed slavery less. Nonfree, servile, but nonslave groups became more visible" (op. cit., 151). The Akkadian and Ur Third Dynasty empires exemplify corvée organization without slavery. Mann even reported a further stage of institutionalised compulsive labor: "free" or "hired labor."

Hired labor exists under the most secure conditions of stratification and private property where some group de facto "owns" the means of production and others must work for this to subsist. In this case, workers "voluntarily" enter into an employment relationship with owners. This type of labor, based on economic compulsion, was not dominant in the ancient world, because in an agrarian society it would be difficult to exclude peasants completely from direct access to their principal means of production: the land. "Once in possession, he or she was more often coerced directly through slavery or serfdom" (op. cit., p. 152). The separation of production process and supra-economic (coercive) power is an established fact in a capitalist system, but it does not exist under other systems such as compulsory co-operation, slavery, or serfdom (Vahabi 2004, chapter 1). In pre-capitalist systems, productive systems were founded on personal subordination, whereas
} 
Moreover, his hypothetical assumption was neither false nor true in itself: it simply postulated a state within which the analysis is conducted. Williamson's research program (i.e., an investigation of the boundaries of firms) was completely consistent with the dismissal of an initial Hobbesian state or Leviathan. The assumption does, however, have a direct consequence. By narrowing the scope of transaction costs, Williamson categorically excluded theft, predation, any appropriative activity, and violent enforcement from his transactional analysis.

Williamson's (1985: 47) definition of opportunism as "self-interest with guile" includes blatant forms of opportunism such as lying, stealing, and cheating, but he focuses on more subtle types of deceit, particularly adverse selection and moral hazard as subtle forms of ex ante and ex post opportunism. In other words, he favors the forms of cheating that can arise within the contractual relationship and not those without this relationship. He is not concerned with theft and capture as part of appropriative allocation, but he is concerned with cheating within the exchange relationship. Thus, he tackles the question of enforcement from the perspective of a "grand transformation" (Williamson 1985), a process in which generic assets are increasingly superseded by idiosyncratic or specific assets.

Similarly, Williamson assumed enforcement to be imperfect (otherwise opportunism would never pay), but his analysis did not include this as an explicit variable. While selfenforcement and bilateral (internal) contractual enforcement were crucial to Williamson's argument, his analysis lacked a third-party (external) violence-using enforcer. As noted above, Williamson (1992: 340) considered the firm's hierarchy to act as a "private" court: "The efficacy of fiat turns critically on the part that hierarchy is its own court of appeal." North (1990a: 54) argued that this lack of emphasis on enforcement is a major difference between how Williamson and the University of Washington branch approach transaction costs: "Such an approach simply does not lead the scholar to be able to deal with the problems of historical evolution." Dealing with historical evolution from a transactional perspective requires extending transaction costs to politics and pre-capitalist social institutions such as slavery and serfdom. Transaction costs are not therefore specific to capitalist governance structures; they become the alpha and omega of social evolution throughout history. This is at the core of the University of Washington branch's approach to property rights.

\section{In the beginning there was a Hobbesian state}

Coase's second seminal paper was a major source of inspiration for the University of Washington branch of property rights. This second paper introduced what Stigler first termed the Coase theorem, which he defined as, “...under perfect competition private and social costs will be equal" (Stigler 1966: 113). Coase (1988b: 158) later provided his own modified definition of the theorem: “...with zero transaction costs, private and social costs will be

in the capitalist system, the productive system depends upon economic or impersonal subordination of labor to capital (Marx 1973; Simmel 1987). 
equal". From this perspective, the problem of social cost arises either in the absence of exclusive rights (hence the absence of the right to contract), or in cases where the right to contract exists but transactions costs are high. "Externalities" are simply specific cases of positive transaction costs.

Cheung was the first to recognize that the Coase theorem (1960) undermines the very notion of externality. He wrote, "The concept of "externality" is vague because every economic action has effects; it is confusing because classifications and theories are varied, arbitrary, and ad hoc. For these reasons, theories generated by the concept of "externality" are not likely to be useful" (Cheung 1970: 70). Therefore, "transaction costs" should replace "externality" entirely, thereby dismissing theories based on the idea of externality. ${ }^{7}$ However, by extending transaction costs to cover all forms of externality, transaction costs could become as vague as externality. For this reason, it might be useful to delimit the scope of transaction costs.

The whole idea of the Coase theorem was to construct an imaginary or hypothetical state in which property rights are so perfect that transaction costs are nil. All other "inefficient" property regimes throughout history should be measured against this ideal property regime; the extent of their distance from the ideal regime can be gauged by the amount of transaction costs. Cheung (1974) and Barzel (1985: 7, 11, 12) assumed that when property rights are perfect, by definition no theft can take place and as a result, no effort is made to protect rights. The next section will show that Coase $(1959,1960)$ was unable to postulate such a pure or ideal state, because he believed that blackmail or extortion could not be excluded, even in a zero transaction cost state. However, the extension of the Coase theorem to all forms of externalities led to its application to a Hobbesian state.

Unlike markets, the study of a Hobbesian state was relegated to political science until recently. Public choice economists pioneered the study of anarchic or Hobbesian states in the 1970s (Powell and Stringham 2009). Little historical evidence is available to show how humans actually behave in a "state of nature" (Powell and Wilson 2008), but Hobbes's state of nature has served as the analytical starting point for economists studying anarchy and the foundation of government.

Early public choice scholars, notably Buchanan (1975), Bush (1972), Bush and Mayer (1974), Olson (1965, 1982), and Tullock (1972, 1974a,b) tackled anarchy and genuine political violence within the context of a coercive relationship. They studied not only threat power but also real conflictual situations such as revolutions and wars. (Buchanan 1992: 116) described the public choice research program as tackling questions such as, "What were the descriptive features of Hobbesian anarchy? Could something like an anarchistic equilibrium be defined? Bush was instrumental in organizing a series of weekly workshops in 1972 during which each participant in turn presented papers on differing aspects of the theory of anarchy".

\footnotetext{
7 This includes rent-seeking theories (Tullock 1967; Krueger 1974), which were contested by Cheung (1974) and Barzel $(1974,2002)$. This issue will be discussed in more detail in the final section.
} 
The Olsonian distinction between roving and stationary bandits (Olson 1982) illustrates the rationale behind the transition from anarchy to the emergence of the State. Roving bandits have such a narrow stake in any loss or benefit to society that they ignore the harm to society caused by their marauding; their interest regarding the overall effect of their actions to society is narrow. In contrast, stationary bandits controlling a territory (e.g., Mafia families or states) monopolize crime or coercive means in a community; stationary bandits have a moderately encompassing interest in the income of that community. Accordingly, they consider the overall effects of their actions on society when resorting to coercive power.

Olson applied this distinction to explain the origin of the State. Roving banditry means anarchy, and replacing anarchy with government brings about a considerable increase in output. Kurrild-Klitgaard and Svendsen (2003) provided an illustration for Olson's insights by studying the Vikings' activities and settlements. Their model suggested that Viking-like bandits engaging in roving banditry might have been over-plundering. The state-making of Viking rulers was then explained in terms of increased profits due to stationary banditry. Interestingly, this is consistent with empirical observations about the number of raids and the amount of wealth extorted by Viking kings.

Anarchy is sometimes understood as chaos and mayhem, but it can also be described as a society without a state but not without rules (Coyne 2005). The main issue here is whether an "ordered anarchy" (i.e., a social order without a state) is possible (Vahabi 2009a). Early critics of anarchy (Tullock 1972, 1974a; Nozick 1974) were almost unanimous in their opinion that government is at least inevitable even if unnecessary, but many recent public choice scholars, such as Bruce Benson, Robert Ekelund, and Antony de Jasay, have questioned this assumption (Powell and Stringham 2009). These modern scholars do not always view anarchy as a prisoners' dilemma where government would be the unique solution. Although they disagree about the stability of an ordered anarchy, all public choice scholars agree that anarchy cannot be dealt with by extending the market model of voluntary transactions to coercive power. The opposite holds true for the founders of the University of Washington branch of the property rights approach.

While the asset-specificity school is based on the assumption that "in the beginning, there were markets" (Williamson 1985), the University of Washington branch begins with a "Hobbesian state" preceding market relationships and embracing conflictual and coercive relationships. "The model's onset is at a time that precedes any voluntary social interactions. Individuals lived then in a Hobbesian "state of nature." Those who survived obviously were able to keep at least some of what they gathered and hunted (...) They had to protect what they got, and thus they incurred transaction costs (as the term is defined here)" (Barzel 2002: 267-68, emphasis added). Here, transaction costs are defined as protection and aggression costs and are extended to include the pre-exchange Hobbesian state. Following Allen (1991), Barzel linked transaction costs to economic rights: transaction costs are thus the resources used to establish and maintain property (i.e., economic) rights. 
According to Barzel (2002), individuals initially have no legal rights over the assets they acquire, as no legal institutions exist. However, they have (at least partially, by might) "economic rights" akin to Hobbes's "natural rights" over these assets. Transaction costs thus include the appropriative allocation of resources through capture and theft: "Indeed, you own today even the apples you intend to steal from your neighbor's tree tomorrow. Because the chance is positive that assets will be captured or stolen, assets that may appear fully owned are owned only in part. The probability that an asset will be stolen (or captured), as well as the level of its protection, will depend on its value" (Barzel 2002: 15). Barzel's explanation of transaction costs does not fall under the Coaseian paradigm of mutual advantageous exchange relationships; it is more closely related to the Hobbesian state of capture and predation.

Like Barzel, North considered transaction costs to include the costs of delineating, measuring, and enforcing property rights (North and Thomas 1973: 5; North 1981: 145; North 1990a: 27; North 1992: 6-8; North 1993: 18). Accordingly, transaction costs are associated with the costs of third-party violence-using enforcement (particularly the emergence of the state enforcement) to secure property rights.

The difference in the basic analytical framework (market versus Hobbesian state) lies in the "economic" or "extra-economic" nature of transaction costs. While the asset-specificity branch focuses on the subtle forms of opportunism that arise within contractual relationships (moral hazard and adverse selection), the University of Washington branch focuses on strong forms of opportunism (such as theft and predation), which exist outside the contractual relationship. Similarly, external enforcement plays either a derisory or principal role in each branch; Table 2 summarizes the differences between the two.

Table 2. Differences between the two branches of the property rights approach

\begin{tabular}{|c|c|c|c|c|}
\hline $\begin{array}{c}\text { Branch of the } \\
\text { property rights } \\
\text { approach }\end{array}$ & $\begin{array}{c}\text { Basic } \\
\text { analytical } \\
\text { framework }\end{array}$ & Type of opportunism & $\begin{array}{c}\text { Type of } \\
\text { enforcement }\end{array}$ & $\begin{array}{c}\text { Type of transaction } \\
\text { costs }\end{array}$ \\
\hline $\begin{array}{c}\text { Asset- } \\
\text { branch }\end{array}$ & Market & $\begin{array}{c}\text { Subtle (within the } \\
\text { contractual } \\
\text { relationships: moral } \\
\text { hazard and adverse } \\
\text { selection) }\end{array}$ & $\begin{array}{c}\text { Self-enforcement } \\
\text { or bilateral } \\
\text { internal } \\
\text { enforcement }\end{array}$ & $\begin{array}{c}\text { Economic } \\
\text { (associated with } \\
\text { governance } \\
\text { structures) }\end{array}$ \\
\hline $\begin{array}{c}\text { University of } \\
\text { Washington } \\
\text { branch }\end{array}$ & $\begin{array}{c}\text { Hobbesian } \\
\text { state }\end{array}$ & $\begin{array}{c}\text { Strong (outside the } \\
\text { contractual } \\
\text { relationships: theft } \\
\text { and predation) }\end{array}$ & $\begin{array}{c}\text { External } \\
\text { violence-using } \\
\text { enforcement }\end{array}$ & $\begin{array}{c}\text { Supra-economic } \\
\text { (associated with all } \\
\text { forms of } \\
\text { "externalities") }\end{array}$ \\
\hline
\end{tabular}

When transaction costs are extended beyond governance structures, the two branches of property rights produce contradictory results. According to the asset-specificity branch, generic assets are compatible with an impersonal market in the absence of a long-term 
contractual relationship. However, asset specificity and transaction costs will grow due to gradual increases in the amount and frequency of particular investments. Idiosyncratic investments will lead to a bilateral monopoly, resulting in situations in which contractual agreements are important to curb opportunistic behavior. Finally, face-to-face relationships result in bilateral and unified governance structures in which market allocation of resources is replaced by hierarchical (firm) coordination to minimize transaction costs. The fiat or discretionary power of the firm's hierarchy constitutes a sort of tribunal for ultimate appeal. Of course, with greater asset specificity, the observable terms of contracts for the parties become increasingly unverifiable by a third party (a court or the State). This imperfect nature of external enforcement by a third party supports the need for internal enforcement, or lateral and vertical integration.

Barzel and North focused on theft and capture, and thus on third-party violence-using enforcement. In their model, the transaction costs of this enforcement are especially high in impersonal markets, because these are at greater risk of theft (outside the exchange relationship, and within an appropriative allocation). Generic assets are more easily subject to capture and hence entail higher transaction costs. Anonymity and lack of long-term relationships, which are common in caveat-emptor and future-delivery transactions (Barzel 2002: 84-92), imply high transaction costs and use of third-party violence-using enforcement. According to Barzel (2002: 59), "owners of idiosyncratic commodities (...) are expected to protect them by themselves. As these become generic, we expect that (...) the state will undertake the protection."

Should transaction costs for generic assets be gauged as "high" or "low"? According to the asset-specificity branch, these costs are low because they are more easily coordinated through the price mechanism. In contrast, the University of Washington branch would argue that these costs are high because they are more easily subject to capture, and hence entail a higher cost of third-party violence-using enforcement. The opposite holds true for idiosyncratic assets: the asset-specificity branch considers these transaction costs to be high because they involve a more complex exchange process. In contrast, the University of Washington branch considers these costs to be low: "where commodities or services are idiosyncratic (...) enforcing agreements without the use of force is likely to be cheaper" (Barzel 2002: 96). These contradictory results may cast doubt on the validity of transaction costs as a general and allencompassing principle including "all costs incurred in operating an economic system" (North 1992: 6).

The main challenge here is to clarify which level of extension of the Coase theorem undermines its internal logical consistency. In the following sections I will examine first, whether Coase theorem is consistent with appropriative activity, and second, whether it is consistent with coercive power.

\section{Coase theorem and appropriative activity}


Coase's theorem on externalities and tort law (Coase 1960), which Olson (2000) aptly referred to as "the concept of voluntary exchange and Coaseian bargains" has been formulated in many ways by various authors. Coase's (1998b: 165) own formulation was: "With zero transaction costs, the allocation of resources will remain the same whatever the legal position regarding liability for damage." This keeps the liability issue at the core, as it has been in Coase's publications since his first paper on the social problem.

David Cavers, a lawyer and friend of Coase, pointed out that Coase's article on the Federal Communications Commission could allow blackmail or something analogous to it: if someone has a right to commit a nuisance, he or she might threaten to create that nuisance simply to extract money from those who would be harmed by it. Coase (1988a: 658) acknowledged this possibility, because "such activities or threats were a preliminary to an agreement and did not affect the long-run equilibrium. I accepted the fact that bluff and threats were a normal part of business bargaining, and I spoke of the terms of the agreement depending on the shrewdness of the parties."

In other words, Coaseian bargains allow bluffs, threats, and blackmail. ${ }^{8}$ Interestingly, Coase sees blackmail or extortion as possible even when transaction costs are nil. This is in direct opposition to the ideal Coaseian state of zero transaction costs, as assumed by the University of Washington branch of property rights: such an ideal state excludes all forms of extortion. Coase's paper on blackmail (1988a) is particularly illuminating. Using the example of a cattle raiser and a crop farmer, he refuted such an ideal state and clarified the underpinning assumptions of his theorem.

In this paper, Coase demonstrated that if the cattle raiser was liable for the damage caused by his cattle, the crop farmer might plant crops that otherwise would not be profitable, anticipating that the cattle raiser would bribe him not to plant because otherwise he would be liable for the resulting crop damage. Conversely, if the cattle raiser was not liable for the damage caused by his cattle, he might blackmail the crop farmer by augmenting the size of his herd, causing more crop damage; the crop farmer would then pay him to refrain. Coase argued that each party could blackmail the other if he were a potential claimer, though the final outcome would hinge upon the party who could maximize productive value. "My purpose in pointing this out was to show that actions which were undertaken solely for the purpose of being paid not to engage in them, actions which could be called blackmail, would arise whatever the rule of liability or, if you like, the system of rights. I did this not to initiate a discussion of blackmail, but rather to avoid having to do so" (Coase 1988a: 657). So, how did he avoid discussing blackmail?

\footnotetext{
${ }^{8}$ Coase (1988a: 675) defined 'blackmail' as a crime and stressed that "the blackmailer's actions generate fear and anxiety (...) it causes real harm which reduces the value of production." Long before Coase, Nozick (1974) had also described blackmail as a crime. However, Block (1976) and Mack (1982) described blackmail as an exercise of free speech. This debate is beyond the scope of this paper, which focuses on the economic implications of Coase's bargaining mechanism.
} 
Coase used a two-step process. In the first step, he assumed that juridical or institutional rules are given exogenously. At this stage, the juridical or institutional identity of the parties is irrelevant ("irrelevance theorem") in the absence of transaction costs. Then he constructed a hypothetical bargaining process that identifies the party who could maximize the productive value, regardless of the given liability rule. In the absence of transaction costs, this party could receive threat messages since s/he has the most to lose and would want to prevent the loss. The final efficient outcome will be decreased by the amount paid to stop the blackmail if the most productive party is liable.

In the second step, Coase assumed that institutional or juridical rule should be endogenously devised in reality. Because transaction costs are positive in reality, the assumption is that real transactions should be conducted under a juridical rule in which any need for transaction is eliminated. In doing so, the juridical rule should give property rights to the most productive party. Coase (1988a: 673) wrote, "I concluded in 'The Problem of Social Cost' that the value of production would be maximized if rights were deemed to be possessed by those to whom they were most valuable, thus eliminating the need for any transactions." These steps made it possible for Coase to avoid discussing blackmail.

Coase avoided a discussion of real blackmail in the actual bargaining process by introducing blackmail as a threat within a hypothetically costless transaction. However, the final result of this line of reasoning contradicts with the pursuit of minimizing transaction costs. Because a costless transaction does not exclude the possibility of blackmail as part of the bargaining process, costly transactions might improve efficiency by decreasing the possibility of bargaining. Then, higher transaction costs would be preferable. In fact, the law against "blackmail" as a "criminal" action increases transaction costs and improves efficiency. Thus, Pigou's argument cannot be totally dismissed, as state intervention could curb specific negative externalities. However, this is not the only limitation to this argument.

Coase's account of blackmail was conducted within the context of two-party externalities (the cattle raiser and crop farmer). How could this analysis be extended to larger groups and even "amorphous" externalities or public evils such as air pollution? Without citing Coase's paper on blackmail, Schlicht $(1996,1997)$ noted the possibility of extortion within the Coase mechanism ${ }^{9}$ (1960) and cleverly posed this problem within the framework of an iterated extortion process. He illustrated his argument using an example of a factory emitting smoke. The foundation of the firm entails some sunk costs and although it is privately profitable, it is socially inefficient due to the negative external costs of pollution. Once the factory is built and irrecoverable costs are incurred, mutually advantageous bargaining is possible, to the effect that the plant is shut down.

By anticipating this eventual outcome, the parties involved may enter a bargain before any investment is made. The community and the landowner could seek a pre-investment agreement that induces the landowner to dispose of his parcel of land for residential purposes

\footnotetext{
9 Schlict (1996: 326) preferred the term 'Coase mechanism' to 'Coase theorem,' noting that "As Coase (1988) has reminded us, he has never stated such a 'theorem.",
} 
and refrain from erecting the smoke-emitting factory. In other words, the entrepreneur can blackmail the community and be bribed to refrain from using his destructive power. But suppose that once this problem is solved, another entrepreneur comes up with a similar proposal? The community might pay an additional side-payment to prevent the socially harmful activity. However, Schlicht (1996: 321) noted that "if the process continues, the sum total of all side-payments may surpass the value of the asset. If this is anticipated, nobody will be prepared to offer side-payments in the first place. The Coase bargaining mechanism will be blocked, and the harmful activity may be carried through if the prevailing set of property rights permits."

Schlicht's model demonstrated that if the amount of extortion exceeds the productive value, then the Coase mechanism will be blocked. However, this problem exists even without any iteration in the case of bargaining games with non-cooperative outcomes in which the parties involved cannot agree on the distribution rule. Thus, Coaseian bargaining could be blocked even when transaction costs are nil.

The bargaining version of the Coase theorem is based on an optimistic attitude about the ability of individuals to agree upon the distribution rule. The assumption is that the major obstacles are communication between the parties and the costs incurred in negotiating and enforcing agreements. Transaction costs are thus considered to be the main issue. However, it is possible to imagine zero transaction costs. Would costless transactions be sufficient to ensure that the parties involved would strike an agreement on the distribution rule? Probably not, because efficiency considerations cannot be separated from distributional conflicts. ${ }^{10}$ The problem with Coaseian bargaining is that it assumes solved social (distributional) conflicts and then proceeds to show the efficiency of outcomes stemming from private bargaining (Cooter 1982; Vira 1997; Acemoglu 2003; Vahabi 2010a). Social conflicts are neutral ${ }^{11}$ with regard to the initial assignment of rights or institutional arrangements.

Perhaps the most interesting point about "blackmail" is how the issue opens a Pandora's box of distribution conflicts. Coase's followers prefer to ignore the blackmail issue completely when discussing a zero transaction cost scenario, because their ideal Coaseian state denies the possibility of blackmail. In this way, distributional conflict is wholly excluded from the analysis.

A more pessimistic approach is based on the assumption that individuals will be unable to solve the distribution problem, even if transaction costs are nil. According to Cooter (1982: 17), "There is no reason why rationally interested players should agree about how to divide the stakes. The distribution problem is unsolvable by rational players. To eliminate the

\footnotetext{
${ }^{10}$ See also Knight (1992), who stressed the relationships between institutions and social conflict.

11 A more precise definition of conflict neutrality can be found in Vahabi (2010a: 690): "Neutrality of social conflict connotes a lack of need for real clashing or conflictual action, so a redistribution of wealth or reallocation of resources may occur despite conflictual interests among agents. In a sense, in standard economics, conflict is treated like money: it is neutral with regard to economic performance and disappears in equilibrium. This neutrality is derived from Coasian theorem."
} 
possibility of non-cooperation, we would have to eliminate the problem of distribution, that is, to convert the bargaining game into a coordination game. But it makes no sense to speak about a bargaining game without a problem of distribution." Cooter's alternative "Hobbes theorem" is in direct contrast to the Coase theorem: this Hobbes theorem is based on the assumption that individuals will exercise their worst threats against each other unless a third party coerces both of them. ${ }^{12}$ The intervention of a third party (Hobbes' Leviathan or a dictatorial state) would thus be required to impose a solution.

A recent unpublished manuscript by Demsetz regarding the shortcomings of Pigou's and Coase's arguments about the "problem of social cost" strengthens Cooter's version of the socalled Hobbes theorem. According to Demsetz (2010: 8), positive transaction costs (viewed as the cost of conveying information) like any other types of costs are not the cause of inefficiency, since "there exists an efficient amount of ignorance in an economic system if the cost of acquiring information is positive". Positive transaction costs do not hinder an economic agent's acquisition of information if s/he deems that the costs of acquiring information is less than the value of the knowledge that is expected to be obtained from the information. Of course, one may remember Arrow's caveat that no one could know the value of acquiring any piece of information before obtaining it ${ }^{13}$. But if one follows Demsetz's line of argument, then the only source of inefficiency derives from the strategic behavior of agents in the presence of indivisible goods and services.

The model of perfect decentralization implicitly assumes that goods and services are divisible; the price system is then able to reflect individual demands for these goods and exact individual payments for them. However, when goods are non-excludable, individual preferences may not be revealed, since deceit or strategic behavior may seem remunerative. Under such circumstances, resort to state coercion appears more appealing when free-riding cannot be resolved through private arrangements. "Yet, coercion can be especially useful in cases in which strategic behavior has impaired agreement on production. Just as we find the State's ability to coerce legitimately helpful in the maintenance of law and order, so we may find it useful in helping to finance production of goods and services that are important to society but are subject to serious strategic bargaining problems." (Demsetz 2010: 9-10).

For Demsetz (2008: 115-116) the only true alternative to the market is an institution that can use a greater measure of coercion than is available to agents in the market. This may, thus, be a firm, but "it surely is the state. The court's error might be expeditiously rectified by the government through coercive means that, depending on how one measures the cost of using these means, might be less costly than using voluntarily struck agreements." Demsetz's explanation of the inefficiency seems to be neoclassical, since it refers to indivisibilities. In fact, in a neoclassical approach, the three major reasons for the possible failures of perfect

\footnotetext{
12 This is exemplified in Martin Scorsese's film "Gangs of New York" (2002).

13 Arrow (1962a: 111) states: "There is a fundamental paradox in the determination of demand for information; its value for the purchaser is not known until he has the information, but then he has in effect acquired it witout cost. Of course, if the seller can retain property rights in the use of information, this would be no problem, but given incomplete appropriability, the potential buyer will base his decision to purchase information on less than optimal criteria." This feature of information is known as its inappropriability.
} 
competition to achieve optimality in resource allocation are indivisibilities, inappropriability, and uncertainty. The interesting fact about the information is that it is subject to all the three elements of market failure (Arrow, 1962a: 104-120; 1962b: 129-142; 1965: 191-199). But if transaction costs are the costs of conveying information, why Demsetz excludes positive transaction costs as a source of inefficiency?

The crux of Demsetz's argument is free-riding or strategic behavior and not indivisibilities. Although indivisibilities provide the necessary condition for inefficiency, the cause of it should be sought in free-riding. That explains why Demsetz (2008: 116) strictly distinguishes "transaction costs" from "ownership costs": "The case for the state is strongest in the presence of high costs of barring free riders, costs I would describe as high ownership costs, not as high transaction costs, since the two types of costs need not correlate strongly." This distinction is not new in Demsetz, it is already present in Demsetz (1964). While transaction costs are the costs of using price mechanism, the costs of barring free-riding including the cost of using coercive means or violent enforcement is part of "ownership costs".

According to the Coase theorem, the problem of externalities is related to the cost of the bargaining process; according to the Hobbes theorem, the problem is related to the lack of agreement between private parties due to serious strategic behavior that cannot be resolved without state coercion. Cooter (1982: 18) wrote, "Both of them are false. However, they are illuminating falsehoods because they offer a guide to structuring law in the interest of efficiency."

The Hobbes theorem is an illuminating falsehood because it identifies the limits of Coaseian bargaining with regard to distributional conflicts. Conversely, the extension of Coaseian bargaining to a Hobbesian state reduces all distributional conflicts to a pure problem of transaction costs, even in predatory regimes such as slavery. Barzel (1999: 108) argued that if the monitoring costs of slavery were nil, in conformity with the Coase theorem, slavery would have never existed: "Had all rights been well defined, which requires costless transacting, not only would slave status have been rendered devoid of significance but forced slavery would never have arisen in the first place, since no person would never have captured the rights of others." This line of reasoning has two main problems.

First, it denies any distributional conflict within slavery, as if all problems could be reduced to transactions. Slavery is based not only on the possession of slaves' labor power, but their entire existence, including their bodies. How could this possession be reduced to "monitoring costs?" Coase (1988b: 174) acknowledged the limits of his theorem with regard to such "cataclysmic events as the abolition of slavery," where changes in the assignment of ownership are not neutral with regard to the allocation of resources and economic performance. The Coase theorem rests upon the assumption that wealth effects on demand are negligible, implying that the highest-valued use of resources can be identified independent of the initial rights assignment. This does not apply to a worker's marginal labor when the initial rights assignment could either be slavery or self-ownership. 
The value of an hour of a worker's time to the worker personally is generally greater for a freeman than for a slave. This is not due to transaction costs, but to the non-negligible effect of the initial rights assignment on the worker's wealth. The value of an hour of a slave's leisure time has less market value than his leisure as a freeman ceteris paribus, because a slave has almost no wealth with which to "bid for leisure." Similarly, compared with a freeman, an almost penniless slave has a much lower willingness to pay (to acquire marginal leisure from his owner) than to be paid (to give up leisure). Hence, the higher-valuing party cannot be identified independent of the initial assignment. As White (2008: 332) stressed in his paper on slavery, "The Coasean logic for wealth-maximizing rights assignment applies to decisions where the assignment itself has a negligible effect on bids for alternative uses of the resources being assigned. In slavery versus self-ownership, the assignment has a nonnegligible effect".

The second problem with Barzel's reasoning is that he treated slavery as if it were a contractual relationship between a principal and an agent. In this way, the concept of voluntary transaction and Coaseian bargaining was extended to include relationships based on coercive power. This point will be discussed in more detail in the next section.

\section{Extension of the Coase theorem to coercive power}

Despite the great success of his "Problem of Social Cost" (1960), Coase (1988c) was disappointed that the extensive discussion of the paper in journals focused almost entirely on the Coase theorem. Coase (1988c: 15) wrote, "This response, although disappointing, is understandable. The world of zero transaction costs, to which the Coase theorem applies, is the world of modern economic analysis". However, his concern may have been justified for another reason: The extent of positive transaction costs depends upon the level of generality of the theorem. The more universal the theorem, the more transaction costs will be extended. Hence not only mainstream economists, but also Coase's followers, focused on a general and abstract reformulation of his theorem to the point that transaction costs could be a universal category applicable anywhere and at anytime throughout history.

Coase's initial paper (1960) contained many concrete examples, but it provided no formal or axiomatic demonstration of the theorem. In his subsequent interpretations, Coase (1988c: 1415) claimed the theorem was so general it didn't even require private property rights: "In the absence of transaction costs (...) the institutions which make up the economic system have neither substance nor purpose. Cheung has even argued that if transaction costs are zero, "the assumption of private property rights can be dropped without in the least negating the Coase theorem" and he is no doubt right". In fact, a decentralized market economy requires two basic institutions: 1) a price mechanism; 2) a private ownership system (Demsetz 2010: 5). The zero-transaction costs qualifier assumes a costless price mechanism; but it does not imply costless privatization. Hence, contrary to what Cheung and Coase argue, the assumption of private property rights cannot be dropped when transaction costs are nil. 
A world of zero transaction costs, in which the Coase theorem applies, is now so universally defined that it is marked by an institutional vacuum. ${ }^{14}$ But how is it possible to conceive of commercial bargaining without private property rights?

One of the strongest points of Coase's seminal paper in 1960 was the realistic nature of the bargaining procedure within the context of voluntary private transactions. In the paper, Coase argued that under conditions of zero transaction costs, the allocation of resources will remain the same regardless of the legal position concerning liability for damage. Although the "institutional identity" of the party who was liable or entitled to property rights was irrelevant, Coaseian bargaining was supposed to be based on the institution of market exchange. Can market exchange exist without private property rights? Lange (1936) developed a simulated market exchange without private property rights based on socialism. Is it possible that Coase (1960) was describing a "simulated or hypothetic" market exchange?

In addition, if the assumption of private property rights is excluded, how can Coaseian bargaining be characterized? The fictive and institutional nature of Walras's crieur de prix and his tâtonnement process is understandable as an axiomatic scenario, but is Coaseian bargaining another version of the Walrasian tâtonnement, which does not require any specific institutional environment? The claim of universality implies that Coaseian bargaining can be extended to any institutional scenario, i.e., a voluntary or coercive exchange. Accordingly, any economic system can be depicted as a contractual relationship in which interactions between parties are explained in terms of Coaseian bargaining. All forms of social interactions, including those that are based on explicit use of coercion such as slavery, feudalism, or predatory allocation of resources, can be handled as exchange-like relationships.

Slaves and masters, feudal landowners and serfs, even robbers and victims, supposedly deal with each other according to the rules of Coaseian bargaining. One salient example is the historical analysis of serfdom conducted by North and Thomas (1973). They argued that manorialism is a contractual relationship between the serf and the landowner. In the same vein, North proposed that labor services and other characteristics of serfdom could be explained in terms of "the extremely high transaction costs of forming organized markets precluding specialization and exchange" (North 1981: 129). Surprisingly, the authors inferred the inefficiency of "organized markets" due to the "high transaction costs" in its absence. Early modern European peasants likely made a rational calculation of cost against risk before paying taxes, tithes, and rent. Since most peasants did not rebel or run away, they must have felt that they gained from the transaction, thereby economizing on transaction costs.

The same line of argument can be used for the case of slavery. North (1981: 202) wrote, "The relationship that concerns Meckling and Jensen is a voluntary one; it should be noted that in my framework it may be voluntary or involuntary (such as is slavery)." North's reference to

\footnotetext{
${ }^{14}$ In his earlier reference to the Coase theorem, Cheung (1974: 66-67) cited "private property rights" as one of two conditions the theorem must meet to ensure validity: "In what is now known as the Coase theorem, he proposed (also abstracting from wealth effects) that resource allocation will not be affected regardless of who is liable for any damage if: (1) all use-rights to a good are clearly delineated as private; and (2) all costs associated with contracting and enforcing rights are zero." (emphasis added).
} 
slavery was built on Barzel's (1977) classic article on the topic. ${ }^{15}$ Barzel had tried to show that slavery evolved as a contractual relationship between a master and slave, arguing that a master will gain by transferring certain rights to a slave in return for more output, within the context of principal-agent schemes for motivation structure.

This line of reasoning extends the meanings of "voluntary exchange" and "mutual gain from trade" far beyond their usual connotations. For example, from this perspective a robbery can be defined as an "implicit contract" between victim and robber, in which the robber agrees to save the victim's life in return for a certain amount of money. In reaction to this kind of extension of Coaseian bargaining to a "coercive exchange," Olson (2000: 3) wrote: "For our focus on coercive power and our analysis of self-interested behaviour, I use a criminal metaphor. Clearly, we cannot understand robbery as either a voluntary trade or a moral act, and thus it helps us to focus only on the self-interested use of coercive power".

Allen (1991) provided an enlightening interpretation of property rights. He was aware of the "mysterious" character of transaction costs in the absence of a workable definition. Therefore, Allen (1991: 3) tried to provide a definition that was consistent with the definitions already implicit in many major works involving transaction costs: "Transaction costs are the resources used to establish and maintain property rights". This definition supports the University of Washington branch, and emphasizes the protection of property rights. Consequently, the exclusion of theft or appropriation plays a central role in how the Coase theorem is defined: "When property rights are perfect, no unauthorized transfers in rights can take place (by definition), and as a result, no effort is made to steal or protect those rights" (op. cit).

When there is no need to protect, the state ceases to exist; the key to this definition is not that stealing will not be attempted in a world of zero transaction costs, but that the state withers away. Therefore, a lack of any "unauthorized transfers" implies the existence of "rules" despite the end of the state. Hence, the Coaseian universe of zero transaction costs is assumed to be an anarchic (stateless) society (Moss 1974) or a "social order without the state" (Taylor 1982). The problem is that in such a world, Coaseian bargaining will not be much needed, even in its pure axiomatic version of the "bargaining game." Individuals will instead deal with each other through reciprocity or a pure "cooperation game" as was formalized by Taylor (1987). Moreover, the problem of the distribution rule will also be resolved in a society based on cooperation and reciprocity.

Once again, inconsistencies arise whenever Coaseian bargaining is separated from the context of voluntary market transactions (private property rights) and extended to other forms of institutional scenarios such as a stateless cooperative society. In this sort of situation, Coaseian bargains would be applied indifferently to voluntary transaction, coerced power, and finally to politics. When commenting about the Coase theorem, Olson (2000) was careful to define bargaining as a voluntary transaction.

\footnotetext{
15 In his subsequent book, North (1990a: 32) redefined slavery as an "implicit contract between a master and a slave." To North, slavery exemplified policing agents.
} 
Dixit and Olson (2000) raised the free-riding issue, which arises when the number of people participating in bargaining increases. This is particularly true in the case of amorphous public evils as discussed above. If bargaining is pigeonholed as a voluntary transaction, then all bargaining participants should meet first; Coaseian bargaining will then commence among those who choose to participate. This is a two-stage game that begins with a non-cooperative choice of isolated individuals as to whether they will attend the meeting. Dixit and Olson's model identified the free-riding problem at the first stage and showed the need for coercion to provide public goods in large number settings, where Coaseian bargaining supplies participants with opportunities for free-riding.

But what if the Coaseian theorem is not limited to voluntary transactions and can be extended to coercive power and politics? Cheung (1970: 68) suggested extending transaction costs to the state: "There are reasons to believe that the existence of government lowers transaction costs. But history has repeatedly demonstrated that market response is much quicker than legal response to changing economic conditions. What was not worthwhile to enforce as private yesterday may be so today." Coase (1988c) later conceded that despite serious state failures, in some cases governments could economize on transaction costs better than the private sector.

Interestingly enough, Buchanan is also among the first to advocate for the extension of the Coase theorem to the state, and has written two papers that directly discuss the Coase theorem. In the first article, "The Coase Theorem and the Theory of the State" (Buchanan 1973), he praised Coase's insight for giving the pride of place to fully voluntary and freely negotiated agreements. In this paper, he did not criticize the "zero transactions costs qualifier" in the Coase theorem that he explicitly rejected later in his second seminal paper (Buchanan 1986, 1987). 16 Moreover, in this first paper, he extended the Coase theorem to analyzing the State. Buchanan (1973: 583-584) wrote, "If we remain within the strict contractarian conception of collective action, where all decisions require unanimous consent by all members of the political community, and if we retain the assumption that transactions costs are absent, the Coase theorem on allocational neutrality may be applied beyond those limits within which it has normally been discussed. In this model, collective or governmental decision-making remains equivalent to freely negotiated voluntary exchange" (emphasis added). In other words, the Coase theorem could be extended to "governmental intervention" based on the condition that this intervention would not emerge unless all parties agreed on the contractual terms. But what is the meaning of "governmental intervention" if there is no coercive power?

Buchanan does not extend the Coase theorem to coercive power; he extends it only to a "nonpolitical" state (i.e., one that is not separated from citizens) or a "withering" state. Buchanan (1973: 583) made reference to this type of state when he wrote "There is at least no

16 This paper entitled "Rights, Efficiency, and Exchange: The Irrelevance of Transaction Cost" was initially published in 1984 and republished at least in two of his selected papers (Buchanan 1986, 1987). In this second paper, Buchanan developed a fundamental critique of the Coase theorem from a subjectivist contractarian perspective. 
conceptual or logical necessity to think of "the State" as an entity that exists separate from and apart from citizens". This type of state was also Lenin's ideal type, at least on a theoretical level prior to the Bolshevik revolution. Quoting extensively from Marx, Lenin (1916/1999, chapter 4) referred to such a state as a "non State," 17 and described it as a state that was "withering away" and becoming a non-political, non-coercive state during a transition period towards a Communist society. Contrarily to Lenin, Buchanan (1973) links such type of state to a freely negotiated exchange economy. Even if the Coase theorem is applicable to this type of state, it is not clear if the theorem can be extended to the state as coercive power, separate and apart from citizens.

North $(1989,1990 b)$ extended the Coase theorem to coercive power. He argued for a transaction cost theory of politics and adumbrated the Political Coase Theorem (PCT): "The efficiency of the overall political market is measured by how well the market approximates a zero transaction cost result" (Coase 1990b: 360). ${ }^{18}$ If Coaseian bargaining is extended to political bargaining, then the PCT can be defined as follows: when political transaction costs are nil, political Coaseian bargaining between candidates (or state leaders) and constituents will lead to an efficient solution, regardless of the initial distribution of political entitlements.

According to Buchanan (1987: 158), the thrust of Coase's argument is weakened by the insertion of the transaction costs qualification or proviso: "There is no meaning of the term "allocative efficiency" in an idealized zero transaction-costs setting under the subjectivistcontractarian perspective". From this perspective, the "consensus test" is the unique criterion of efficiency and there is no need for transaction costs. Efficiency is that upon which all potentially affected parties agree, either explicitly or implicitly. ${ }^{19}$ The efficiency criterion is inapplicable in cases of coercive power "To the extent that potential traders are coerced, either by prohibitions on their ability to make enforceable contracts or by the imposition of noncompensated transfers, no conclusions about value-maximizing resource use can be drawn because the rules permit no test" (Ibid.).

Efficiency can be assessed in two ways: first, by assessing Pareto optimality through a strict Pareto test: "An allocation of resources is Pareto superior to an alternative allocation if and only if no person is disadvantaged by it and the lot of at least one person is improved" (Coleman, 1988: 72). The second way is by assessing potential Pareto superiority through the Kaldor-Hicks test; this test is based on the idea that a change is efficient whenever the

\footnotetext{
17 "Marx deduced from the whole history of socialism and the political struggle that the state was bound to disappear, and that the transitional form of its disappearance (the transition from state to non-state) would be the "proletariat organized as the ruling class"” (Lenin 1916/1999: 52).

18 Wittman (1995) argued for a sort of PCT in the case of democratic regimes. Nonetheless, Wittman's reasoning was not confined to democratic institutions, so it can equally be extended to non-democratic political arrangements. Hsiung (2004) also advocated an informal PCT with regard to the Taiwan Strait conflict. Cooter (1995) provided a formal application of the Coase theorem to international relations. See also the entire issue of Japan and the World Economy, Vol. 7, No. 1, May 1995, which is devoted to a discussion of the Coase theorem. 19 Hsiung (2003) suggests that Buchanan's contractarian perspective and the Coase theorem can be reconciled on the basis of a more general criterion of efficiency comprising both the objective "metric of the market" (Coase) and the subjective "metric of the heart" (Buchanan).
} 
winners win more than the losers lose, in the sense that, if the winners could in principle compensate the losers to their satisfaction, the winners would still be better off than they were before the change (Coleman 1988, Chapter 4).

If efficiency is defined in terms of a strict Pareto test, "any starting point will be, or will immediately lead to, an efficient end point, even with transaction costs" (Calabresi 1991: 1215). In this sense, "what is is optimal, until we change it" (op.cit.). This line of argument supports Cheung's (1974: 71) much earlier claim: "Yet in a world where each and every individual is asserted to behave consistently with the postulate of constrained maximization, economic inefficiency presents a contradiction in terms. Even outright mistakes are traceable to constraints of some type. The world is efficient, if the model describing it sufficiently specifies the gains and costs to make it so."

In contrast, the Kaldor-Hicks test of "potential Pareto superiority" requires that part of the gains can be redistributed successfully to losers through various mechanisms, or at least that winners vote or lobby for the compensation of losers. The Political Coase Theorem states that political markets are efficient in terms of potential Pareto superiority when transaction costs are nil. Gary Becker (1983, 1985), Donald Wittman (1989, 1995), Earl Thompson and Roger Faith (1981), Bruce Gardner (1983), and many other scholars have developed various forms of the PCT, focusing on how political bargaining will likely produce efficient results.

Becker (1983, 1985) demonstrated how competition between pressure groups could encourage efficient policies. According to Becker, those who lose from redistribution of income are motivated to minimize their losses. Any redistribution that entails a large loss for a group will meet strong resistance, often curtailing the initial amount. Deadweight losses from redistribution should be added to the losses of losers. The sum total of losses will not help the beneficiaries either: both winners and losers are motivated to minimize excess burden. Therefore, both sides have an incentive to bargain with each another until they maximize joint gains by reducing excess burdens. Coaseian bargaining thus ensures the possibility of efficient allocation of resources. Olson (1990: 34) critically assessed this line of argument and called it "efficient redistribution," concluding that, "If the theory of efficient redistribution is right (...) any redistribution that actually occurs anywhere is quite efficient and so any social costs are small".

Olson correctly predicted Stigler's (1992: 459) subsequent argument about the efficiency of political markets: "Every durable social institution or practice is efficient, or it would not persist". Stigler divided the fields of law and economics into two periods: before Coase's "The Problem of Social Cost" (B.C.) and after Coase's "The Problem of Social Cost" (A.C.). Next, he extended the Chicago School's "perfect markets" model to politics, concluding that all long-lived governmental institutions were efficient by virtue of their survival over a long period.

Wittman (1989, 1995) extended Becker's argument to develop an informal PCT. In his 1989 paper, he argued that inefficiency in government is a result of three possible conditions: 1) extreme voter stupidity; 2) collusion between politicians; and 3) high transaction costs. 
Because voters are generally ignorant rather than stupid, ${ }^{20}$ political markets will be efficient as long as candidates play competitively and transaction costs are nil. In his 1995 book, Wittman argued that democratic societies with rational voters generally produce Paretoefficient results, even maximizing wealth outcomes. He developed his PCT within a democratic context, but his arguments regarding competition among politicians are so general that they do not necessarily require democratic institutions and can even be applied to nondemocratic societies.

If it is true that Coaseian bargaining is not applicable to non-voluntary transactions or coercive power, then all the above theories about the efficiency of political markets are invalid.

Acemoglu (2003) argued that the PCT is an inappropriate framework for analyzing policy and institutional differences across countries, because it does not account for the common occurrence of societies choosing inefficient policies. He supported his argument using a model that explains why powerful groups do not predate efficiently. As an alternative to the PCT, he advocated theories of social conflict that predict the persistence of inefficiencies in social evolution. Basically, these theories blame inefficiencies on the choices of those who control the power: power holders usually pursue their own group's interest rather than the benefit of society as a whole. Thus, their lack of credible commitment is the principal cause of the inapplicability of the PCT. But what about "enlightened dictators" 21 who might predate efficiently?

According to Acemoglu (2003: 623), much of the literature about rent-seeking rules out efficient methods of redistribution and "takes for granted that rent-maximizing behavior by rulers or the government will result in inefficiencies. Our focus is on why efficient policies fail to appear". Unfortunately, Acemoglu did not elaborate on his critical assessment of rentseeking, but his remarks are reminiscent of Cheung (1974: 71) and Barzel's (2002: 129) reflections on rent-seeking: "The term 'rent-seeking' itself is unsatisfactory. The maximization assumption implies that every individual will exploit every profit opportunity. Consequently, all action constitutes rent-seeking. The term, therefore, is superfluous".

A comprehensive discussion of the validity of rent-seeking is beyond the scope of this paper, but one point is important: why will a predatory state necessarily confiscate the property of its subjects only when it can use the property more efficiently than the previous owners could? An efficient predatory state is theoretically conceivable, but the problem is that it does not necessarily predate when the predation is efficient. This discretion of a predatory state stems from its coercive power, which cannot be captured by voluntary transactions. Olson (2000:

\footnotetext{
${ }^{20}$ As Caplan (2005) correctly stressed, Wittman employed the term "ignorance" in its modern usage in academic economics namely random noise. This implies a normally distributed error term with a mean of zero. If the mean error is not zero, then agents would not have rational expectations by definition. An "ignorant" agent makes errors but not systematic ones, whereas a "stupid" agent is irrational and is capable of committing systematic errors.

21 Acemoglu does not use this expression, but his inquiry about "efficient predators" may be linked to such dictators.
} 
61) noted: "The thief need not care whether a fence would pay him as much for what he is taking as it is worth to the victim; murderers do not kill only those who want to commit suicide". Acemoglu's model is useful for showing why dictators should not normally be expected to behave as though they were 'enlightened,' but it does not explain why Olson's supporters are incorrect in arguing that the PCT should not be a benchmark.

After substantiating the inapplicability of the PCT, Acemoglu (2003: 622) paradoxically noted that: "A major challenge for the theories of social conflict is to identify the specific transaction costs that prevent the application of the PCT". This result is in conjunction with Acemoglu's implicit assumption that the PCT, although inapplicable, is a useful benchmark. However, the focus here is on the internal consistency of the PCT itself. Can the logic of coercive power be adequately explained through voluntary transactions? The answer appears to be no, because extension of the Coase theorem to coercion necessarily excludes real conflicts and destruction (Vahabi, 2009b, 2010a, b). Validation of the PCT would require that all conflicts be resolvable through bargaining. This is not necessarily the case in the presence of coercive power. Acemoglu's approach in terms of social conflict appears to be correct: the PCT is not needed as a benchmark.

\section{Conclusions}

In this study, I critically reviewed the evolution of the property rights approach: from the seminal papers published by Coase $(1937,1960)$, through the development of the assetspecificity school, and then the University of Washington school. I demonstrated that the two branches of the property rights approach share many similarities and both are founded on the so-called Coase theorem. However, the two differ greatly with regard to the extension of transaction costs.

The asset-specificity branch confines transaction costs to governance structures in modern capitalist economies; in contrast, the Washington University branch extends the definition of transaction costs to include costs associated with aggression and protection. This broad definition of transaction costs can then be applied not only to modern market economies but also to all pre-capitalist social formations throughout history.

For the property rights approach, the Coaseian universe provides a benchmark for an ideal efficient state where transaction costs are nil. Accordingly, positive transaction costs are defined as the costs that render the Coase theorem inapplicable. The difference between the two branches of the property rights approach concerning the extension of transaction costs hinges upon the scope of applicability of the Coase theorem. The asset-specificity branch narrows the applicability of the Coase theorem to voluntary transactions and excludes the costs associated with appropriation and violent enforcement from transaction costs. In contrast, the University of Washington branch extends the Coase theorem to involuntary transactions and coercive power, and includes the costs of appropriation and violent enforcement in transaction costs. 
These two divergent definitions produce contradictory results regarding the level of transaction costs for generic and idiosyncratic assets. Given the contradictory results, the appropriate scope of the applicability of the Coase theorem becomes controversial. This begs the question: Under which assumptions can transaction costs be extended to appropriative activity and violent enforcement, and are such assumptions consistent with the Coase theorem?

In this paper I demonstrated that extending Coaseian bargaining to appropriation or a Hobbesian state reduces all distributional conflicts to a pure problem of transaction costs, even in predatory regimes such as slavery. However, the highest-valued use of resources cannot be identified independent of the initial rights assignment in the presence of conflict over distributional rule. The problem with Coaseian bargaining is that it assumes solved social (distributional) conflicts and separates efficiency considerations from distributional conflicts. Institutions are then supposed to be efficient because social conflicts are regarded as neutral.

Including the costs of appropriation and violent enforcement within transaction costs requires assuming that Coaseian bargaining can be extended to any institutional scenario, i.e., voluntary as well as coercive exchange. The University of Washington branch of property rights is based on this assumption, and links Coaseian bargaining to a Hobbesian state. However, such an extension undermines the logical consistency of Coaseian bargains as voluntary market transactions. The asset-specificity branch of property rights is closer to Coaseian bargaining when it narrows transaction costs to capitalist institutions. ${ }^{22}$

Voluntary transactions cannot capture the logic of coercive power or social relationships based on compulsion, including slavery, feudalism, and other pre-capitalist social formations. Transaction costs do not include the costs of using coercive power. Protection/aggression costs or ownership costs should be separated from transaction costs.

Extension of the Coase theorem to coercive logic and politics results in the use of the Political Coase Theorem as a benchmark of efficiency. We demonstrated that the assumption of efficient political market is not valid and that the PCT lacks the logical consistency to provide a cornerstone for political theory. This result confirms Olson's (2000: 66) contention that transaction cost "does not provide a sufficient basis for understanding government and politics, or any other sphere of life in which there is compelling authority or coercive power".

Acknowledgements This paper is dedicated to Asghar, Mandana, Regine and Sylvie. The author would like to thank two anonymous referees and the editors, particularly Professor

\footnotetext{
22 I am not advocating the conceptual framework of the asset-specificity branch for use in analyses of governance structures. A critical appraisal of the strengths and weaknesses of this particular school is beyond the scope of this study. The point here is that this approach is more consistent with Coaseian voluntary transactions. Transaction costs appear to be more relevant within the context of modern capitalist institutions, but Coase and his followers never assessed how these could be extended to politics and all other pre-capitalist social formations.
} 
Shughart for their valuable comments and suggestions. All my thanks also go to Ilyess El Karouni, Christophe Defeuilley, and Ekkehart Schlicht for their inspiring and insightful remarks. Obviously, all the remaining errors are mine.

\section{References}

Acemoglu, D. (2003). Why not a political Coase theorem? Social conflict, commitment, and politics. Journal of Comparative Economics, 31, 620-652.

Alchian, A. and Woodword, J. (1988). The firm is dead; long live the firm. Journal of Economic Literature, 26(1), 65-79.

Allen, D. (1991). What are transactions costs? Research in Law and Economics, 14, 1-18.

Allen, D. (2000). Transaction costs. In B. Bouckaert and G. Degeest (Eds.), The Encyclopedia of Law and Economics, Vol. 1: The History and Methodology of law and Economics (pp. 893-926). Cheltenham: Edward Elgar.

Anderson, J. and Marcouiller, D. (2002). Insecurity and the pattern of trade: An empirical investigation. Review of Economics and Statistics, 84(2), 342-352.

Anderson, J. and Marcouiller D. (2005). Anarchy and autarky: Endogenous predation as a barrier to trade. International Economic Review, 46(1), 189-231.

Ankarloo, D. and Paermo, G. (2004). Anti-Williamson: A Marxian critique of new institutional economics. Cambridge Journal of Economics, 28, 413-429.

Arrow, K. (1962a). Economic welfare and the allocation of resources for invention. In K. Arrow (Ed.), The rate and direction of inventive activity: economic and social factors (pp. 609-625). Princeton: Princeton University Press.

Arrow, K. (1962b). The economic implications of learning by doing. Review of Economic Studies, 29, 155-173.

Arrow, K. (1965). Knowledge, productivity, and practice. Bulletin SEDEIS, Etudes no 909, Suppl.

Barzel, Y. (1974). A theory of rationing by waiting. Journal of Law and Economics, 17(1), 73-95.

Barzel, Y. (1977). An economic analysis of slavery. Journal of Law and Economics, 20(1), 87-110.

Barzel, Y. (1982). Measurement cost and the organization of markets. Journal of Law and Economics, 25, $27-$ 48.

Barzel, Y. (1985). Transaction costs: Are they just costs? Journal of Institutional and Theoretical Economics, $141,4-16$.

Barzel, Y. (1997). Economic analysis of property rights (2nd ed.). Cambridge: Cambridge University Press.

Barzel, Y. (1999). Property rights and the evolution of the state. Working Paper, Washington: University of Washington, June.

Barzel Y. (2002). A theory of the state, economic rights, legal rights, and the scope of the state. Cambridge: Cambridge University Press.

Becker, G. (1983). A Theory of competition among pressure groups for political influence. Quarterly Journal of Economics, 98(3), 371-400. 
Becker, G. (1985). Public policies, pressure groups, and dead weight costs. Journal of Public Economics, 28, 329-347.

Berggren, N. and Karlson, N. (2003). Constitutionalism, division of power and transaction costs. Public Choice, 117, 99-124.

Block, W. (1976). Defending the undefendable: The pimp, prostitute, scab, slumlord, libeler, moneylender, and other scapegoats in the rogue's gallery of American society. New York: Fleet Press Corp.

Bowles, S. and Jayadev, A. (2007). Garison America. Economics Voice. The Berkeley Electronic Press, March, www.bepress.com/ev

Buchanan, J. (1973). The Coase theorem and the theory of the state. Natural Resources Journal, 13, 579-594.

Buchanan, J. (1975). The limits of liberty: between anarchy and Leviathan. Chicago: Chicago University Press.

Buchanan, J. (1986). Liberty, market, and state: political economy in the 1980s. Brighton/Sussex: Wheatsheaf Books.

Buchanan, J. (1987). Economics: between predictive science and moral philosophy. College Station, TX Texas: A \& M University Press.

Buchanan, J. (1992). Better than plowing and other personal essays. Chicago: Chicago University Press.

Bush, W. (1972). Individual welfare in anarchy. In G. Tullock (Ed.), Explorations in the theory of anarchy (pp. 5-18). Blacksburg, VA: Center for the Study of Public Choice.

Bush, W. and Mayer, L. (1974). Some implications of anarchy for the distribution of property. Journal of Economic Theory, 8, 401-412.

Calabresi, G. (1991). The pointlessness of Pareto: Carrying Coase further. Yale Law Journal, 100(5), 12111237.

Caplan, B. (2005). From Friedman to Wittman: The transformation of Chicago political economy. Economic Journal Watch, 2(1), 1-21.

Cheung, S. (1969). A theory of share tenancy. Chicago: University of Chicago Press.

Cheung, S. (1970). The structure of a contract and the theory of a non-exclusive resource. Journal of Law and Economics, 13(1), 49-70.

Cheung, S. (1974). A theory of price control. Journal of Law and Economics, 17, 53-72.

Coase, R. (1937). The nature of the firm. Economica, 4(16), 386-405.

Coase, R. (1959). The federal communications commission. Journal of Law and Economics, 2, 1-40.

Coase, R. (1960). The problem of social cost. Journal of Law and Economics, 3, 1-44.

Coase, R. (1988a). Blackmail. Virginia Law Review, 74(4), 655-676.

Coase, R. (1988b). Six: Notes on the problem of social cost. In R. Coase, The firm, the market and the law (pp. 157-185). Chicago and London: The University of Chicago Press.

Coase, R. (1988c). One: The firm, the market, and the law. In R. Coase, The firm, the market and the law (pp. 131). Chicago and London: The University of Chicago Press.

Coase, R. (1992). The institutional structure of production. American Economic Review, 82(4), 713-719.

Coleman, J. (1988). Markets, morals and the law, Cambridge: Cambridge University Press. 
Cooter, R. (1982). The cost of Coase. The Journal of Legal Studies, 11(1), 1-33.

Cooter, R. (1995). The Coase theorem and international economic relations. Japan and the World Economy, $7(1), 29-44$.

Coyne, C. (2005). Social interaction without the state. In E. Stringham (Ed.), Anarchy, State and Public Choice (pp. 49-59). Cheltenham and Northampton: Edward Elgar.

Demsetz, H. (1964). The exchange and enforcement of property rights. Journal of Law and Economics, 7, 1126.

Demsetz, H. (1988). The theory of the firm revisited. Journal of Law and Economics and Organization, 4, 141161.

Demsetz, H. (1997). The economics of the business firm: seven critical commentaries. Cambridge; New York: Cambridge University Press.

Demsetz, H. (2008). From economic man to economic system: essays on human behavior and the institutions of capitalism. Cambridge; New York: Cambridge University Press.

Demsetz, H. (2010). The problem of social cost: What problem? Unpublished Manuscript, Los Angeles, California: University of California.

Dietrich, M. (1994). Transaction cost economics and beyond. London: Routledge.

Dixit, A. and Olson, M. (2000). Does voluntary participation undermine the Coase theorem? Journal of Public Economics, 76, 309-335.

Fourie, F. (1993). In the beginning there were markets? In C. Pitelis (Ed.), Transaction costs, markets and hierarchies. Oxford: Basil Blackwell.

Gardner, B. (1983). Efficient redistribution through commodity markets. American Journal of Agricultural Economics, 65, 225-34.

Garfinkel, M. and Skaperdas, S. (2007). Economics of conflict: An overview. In T. Sandler and K. Hartley (Eds.), Handbook of defense economics, Volume 2, Defense in a globalized world (Chapter 22, pp. 649-709). Amsterdam: North-Holland.

Hicks, J. (1935). A suggestion for simplifying the theory of money. Economics, 2, 1-19.

Hodgson, G. (1988). Economics and institutions, a manifesto for a modern institutional economics. Cambridge: Polity Press.

Hsiung, B. (2003). Reconciling Coase and Buchanan on the Coase theorem. Journal of Institutional and Theoretical Economics, 159, 392-413.

Hsiung, B. (2004). Coase theorem and the Taiwan strait conflict. Kyklos, 57(4), 505-518.

Jayadev, A. and Bowles, S. (2006). Guard labor. Journal of Development Economics, 79, 328-348.

Knight, J. (1992). Institutions and social conflict. Cambridge: Cambridge University Press.

Krueger, A. (1974). The political economy of the rent-seeking society, American Economic Review, 64(3), 291303.

Kurrild-Klitgaard, P. and Svendsen, G. T. (2003). Rational bandits: Plunder, public goods, and the Vikings. Public Choice, 117(3-4), 255-272.

Lange, O. (1936/1964). On the economic theory of socialism. In B. Lippincott, (Ed.), On the economic theory of socialism (pp. 55-143). New York: McGraw-Hill. 
Lenin, V.I. (1916/1999). The state and revolution. Chippendale, Australia: Resistance Books.

Long, N. and Sorger, G. (2004). Insecure property rights and growth: The roles of appropriation costs, wealth effects, and heterogeneity. CESIFO Working Paper, No. 1253, August, www.ssrn.com

Mack, E. (1982). In defense of blackmail. Philosophical Studies, 41(2), 273-284.

Mann, M. (1986). The sources of social power, vol. 1, A history of power from the beginning to A.D. 1760. Cambridge: Cambridge University Press.

Marx, K. (1867/1978). Capital, a critique of political economy, 3 Volumes. Moscow: Progress Publishers.

Marx, K. (1973). Grundrisse. New York, Vintage Books.

Medema, S. and Zerbe, R. (2000). The Coase theorem. In B. Bouckaert and G. De Geest (Eds.), Encyclopedia of law and economics, Vol. I (pp. 836-92). Cheltenham, Edward Elgar.

Milonakis, D. and Fine, B. (2007). Douglass North's remaking of economic history: A critical appraisal. Review of Radical Political Economics, 39, 27-57.

Moss, L. (1974). Private property anarchism: An American variant. In G. Tullock (Ed.), Further explorations in the theory of anarchy (pp. 1-31). Blacksburg,VA: Center for the Study of Public Choice.

North, D. and Thomas, R. (1973). The rise of the Western world, a new economic history. Cambridge: Cambridge University Press.

North, D. (1977). Markets and other allocation systems in history: The challenge of Karl Polanyi. Journal of European Economic History, 6, 703-16.

North, D. (1981). Structure and change in economic history. New York, London: W.W. Norton and Company.

North, D. (1989). A transaction cost approach to the historical development of politics and economies. Journal of Institutional and Theoretical Economics, 145, 661-668.

North, D. (1990a). Institutions, institutional change and economic performance. Cambridge: Cambridge University Press.

North, D. (1990b). A Transaction Cost Theory of Politics. Journal of Theoretical Politics, 2(4), 355-367.

North, D. (1992). Transaction costs, institutions, and economic performance. International Centre for Economic Growth, Occasional Papers, No. 30, 32 pages.

North, D. (1993). Institutions and credible commitment. Journal of Institutional and Theoretical Economics, 149(1), 11-23.

Nozick, R. (1974). Anarchy, state, and utopia. New York: Basic Books.

Olson, M. ([1965] 1980). The logic of collective action, public goods and the theory of groups. Cambridge Mass., London: Harvard University Press.

Olson, M. (1982). The rise and decline of nations: Economic growth, stagflation, and social rigidities. New Haven: Yale University Press.

Olson, M. (1990). How bright are the northern lights? Some questions about Sweden. Lund: Institute of Economic Research, Lund University. 
Olson, M. (2000). Power and prosperity, outgrowing Communist and Capitalist dictatorships. New York: Basic Books.

Palermo, G. (2000). Economic power and the firm in new institutional economics: The conflicting problems. Journal of Economic Issues, 34(3), 573-601.

Pareto, V. (1927/1971). Manual of Political Economy. New York: A. M. Kelley.

Powell, B. and Wilson, B. (2008). An experimental investigation of Hobbesian jungles. Journal of Economic Behavior and Organization, 66, 669-686.

Powell, B. and Stringham, E. (2009). Public choice and the economic analysis of anarchy: A survey. Public Choice, 140, 530-538.

Samuels, W. J. (1974). The Coase theorem and the study of law and economics. Natural Resource Journal, $14(1), 1-33$

Schlag, P. (1989). The problem of transaction costs. Southern California Law Review, 62, 1661-1699.

Schlicht, E. (1996). Exploiting the Coase mechanism: The extortion problem. Kyklos, 49(3), 319-330.

Schlicht, E. (1997). The Coase mechanism and the iteration argument: Reply. Kyklos, 50(4), 581-585.

Simmel, G. (1987). Philosophie de l'argent. Paris: PUF.

Skaperdas, S. and Syropoulos, C. (2002). Insecure property and the inefficiency of exchange. Economic Journal, $112,133-146$.

Smith, A. (1776/1961). An inquiry into the nature and causes of the wealth of nations. London: Methuen.

Stefanadis, C. (2007). Appropriation, property rights, and openness to international trade. Working Paper, Department of Agricultural and Resource Economics, University of Arizona.

Stigler, J. (1966). The theory of price (3rd ed.). New York: Macmillan Co.

Stigler, G. (1992). Law or economics? Journal of Law and Economics, 35(2), 455-468.

Taylor, M. (1982). Community, anarchy and liberty. Cambridge: Cambridge University Press.

Taylor, M. (1987). The possibility of cooperation. Cambridge University Press: Cambridge.

Thompson, E. and Faith, R. (1981). A pure theory of strategic behavior and social institutions. American Economic Review, 71, 366-80.

Tilly, C. (1985). War making and state making as organized crime. In T. Skocpol and P. Evans (Eds.), Bringing the state back in. Cambridge: Cambridge University Press, 169-191.

Tornell, A. and Velasco, A. (1992). The tragedy of commons and economic growth. Journal of Political Economy, 100, 1208-1231.

Tornell, A. and Lane, P. (1999). The Voracity effect. The American Economic Review, 89, 22-46.

Tullock, G. (1967). The welfare costs of tariffs, monopolies, and theft. Western Economic Journal, 5(3), 224232.

Tullock, G. (Ed.). (1972). Explorations in the theory of anarchy, Blacksburg, VA: Center for the Study of Public Choice. 
Tullock, G. (Ed.). (1974a). Further explorations in the theory of anarchy, Blacksburg, VA: University Publications.

Tullock G. (Ed.). (1974b). The social dilemma: The economics of war and revolution, Blacksburg, VA: University Publications.

Vahabi, M. (2002). From the Walrasian general equilibrium to incomplete contracts: Making sense of institutions. Economie et institutions (Economics and Institutions), 1, 99-143.

Vahabi, M. (2004). The political economy of destructive power, Cheltenham: Edward Elgar.

Vahabi, M. (2009a). An introduction to destructive coordination. American Journal of Economics and Sociology, 68(2), 353-386.

Vahabi M. (2009b). A critical review of strategic conflict theory and socio-political instability models. Revue d'Economie Politique, 119(6), 679-720.

Vahabi, M. (2010a). Integrating social conflict into economic theory. Cambridge Journal of Economics, 34(4), 687-709. doi:10.1093/cje/bep 043, 14 July 2009.

Vahabi, M. (2010b, forthcoming). Economics of destructive power. In D. Braddon and K. Hartley, Elgar handbook on the economics of conflict (Chapter 5), Cheltenham: Edward Elgar.

Vira, B. (1997). The political Coase theorem: Identifying differences between neoclassical and critical institutionalism. Journal of Economic Issues, 31(3), 761-779.

Wallis, J. and North, D. (1986). Measuring the transaction sector in the American economy, 1870-1970. In S. Engerman and R. Gallman (Eds.), Long Term Factors in American Economic Growth (pp. 95-148). Chicago: Chicago University Press.

Wallis, J. and North, D. (1988). Should transaction costs be subtracted from gross national product. The Journal of Economic History, 48(3), 651-654.

White, L. (2008). Can economics rank slavery against free labor in terms of efficiency? Politics, Philosophy \& Economics, 7, 327-340.

Williamson, O. (1975). Markets and hierarchies: Analysis of anti-trust implications. New York: Free Press.

Williamson, O. (1979). Transaction cost economics: The governance of contractual relations. Journal of Law and Economics, 22(2), 233-261.

Williamson, O. (1985). The economic institutions of Capitalism. firms, markets, relational contracting. New York: Free Press.

Williamson, O. (1989). The firm as a nexus of treaties: An introduction. In M. Aoki, B. Gustafsson, and O. Williamson (Eds.), The firm as a nexus of treaties (pp. 1-26). London: SCASS, Sage Publications.

Williamson, O. (1992). Markets, hierarchies, and the modern corporation: An unfolding perspective. Journal of Economic Behavior and Organization, 17(3), 335-352.

Williamson, O. (1996). The mechanisms of governance. Oxford: Oxford University Press.

Wittman, D. (1989). Why democracies produce efficient results. The Journal of Political Economy, 97(6), 13951424.

Wittman, D. (1995). The myth of democratic failure: Why political institutions are efficient. Chicago: Chicago University Press. 